\title{
Active Oxygen by Ce-Pr Mixed Oxide Nanoparticles Outperform Diesel Soot Combustion Pt Catalysts
}

\author{
Noelia Guillén-Hurtado, Avelina García-García, Agustín Bueno-López*
}

\author{
Department of Inorganic Chemistry; University of Alicante \\ Carretera de San Vicente s/n 03690. San Vicente del Raspeig - Alicante (Spain) \\ Fax: (+34) 965903454 \\ *Corresponding author: agus@ua.es
}

Abstract:

A $\mathrm{Ce}_{0.5} \mathrm{Pr}_{0.5} \mathrm{O}_{2}$ mixed oxide has been prepared with the highest surface area and smallest particle size ever reported (125 $\mathrm{m}^{2} / \mathrm{g}$ and $7 \mathrm{~nm}$ respectively), also being the most active diesel soot combustion catalyst ever tested under realistic conditions if catalysts forming highly volatile species are ruled out. This Ce-Pr mixed oxide is even more active than a reference platinum-based commercial catalyst. This study provides an example of the efficient participation of oxygen species released by a ceria catalyst in a heterogeneous catalysis reaction where both the catalyst and one of the reactants (soot) are solids. It has been concluded that both the ceria-based catalyst composition (nature and amount of dopant) and the particle size play key roles in the combustion of soot through the active oxygen-based mechanism. The composition determines the production of active oxygen and the particle size the transfer of such active oxygen species from catalyst to soot.

Keywords: Nanoparticles; Radicals; Ceria; Soot; Active oxygen 


\section{1.- Introduction}

A typical heterogeneous catalysis reaction consists of a liquid or gas effluent whose molecules are adsorbed and react on the surface of a solid catalyst. The rate limiting step of this type of reactions can be either a chemical process occurring on the catalyst surface, the diffusion of the reactant molecules from the effluent bulk to the catalyst active sites or the release and diffusion of the reaction products from the catalyst surface back to the effluent bulk.

The combustion of diesel soot (solid carbon particles) accelerated by a solid catalyst can be considered, in somehow, a heterogeneous catalysis reaction, because the oxidizing species (mainly $\mathrm{O}_{2}$ and $\mathrm{NOx}$ ) are gases. However, it has the particular feature that one of the reactants, the soot carbon particles, is in solid state. This hinders significantly the performance of a solid catalyst due to the poor contact between the solid particles of soot and catalyst. In this reaction, the rate limiting step can additionally be the transfer of reaction intermediates from the catalyst surface to the soot particles, which in a real application is often restricted to the few contact points existing between soot and catalyst particles.

Important research efforts have been done during the last years in order to develop a suitable soot removal system for diesel vehicles [1, 2], because diesel soot is responsible of severe environmental and health problems [3, 4]. Typically, soot particles are collected in a filter placed in the exhaust pipe, and a catalyst is used in most cases to lower the soot combustion temperature $[5,6]$. In order to solve the problem of the poor soot-catalyst contact, several strategies have been proposed. One of them consists of the impregnation of a low melting temperature catalyst, like a eutectic salt mixture $\left(\mathrm{Cs}_{2} \mathrm{SO}_{4} \cdot \mathrm{V}_{2} \mathrm{O}_{5}\right.$, for instance [7]) or an alkali compound (a potassium salt, for instance 
[8]) into the filter. This type of catalysts melt under reaction conditions, and once in liquid phase, the contact with the soot particles is significantly improved. Unfortunately, these catalysts are progressively evaporated and have no practical relevance. Some other highly active catalysts, like those of ruthenium, iridium or osmium have neither practical interest because of the formation of volatile oxides [9, 10].

An elegant solution was found by Johnson Matthey, which is currently commercially available for heavy duty diesel vehicles like trucks and buses [11]. This system consists of a platinum-containing oxidation catalyst located upstream the soot filter. The platinum catalyst oxidizes the $\mathrm{NO}$ emitted by the engine to $\mathrm{NO}_{2}$, which is much more oxidizing than $\mathrm{NO}$ and $\mathrm{O}_{2}$ and initiates the oxidation of the soot collected downstream. This approach solves the problem of the poor soot-catalyst contact by using the high oxidation capacity of $\mathrm{NO}_{2}[11]$.

Platinum catalysts are the most active ones for diesel soot oxidation in real conditions so far, but some other solid catalysts are being investigated to improve the activity and lower the price. Doped cerium oxides, and Ce-Pr mixed oxides in particular, are among the most promising candidates to replace platinum, because they are able to produce highly oxidizing active oxygen species [12-16]. This highly reactive active oxygen is produced by oxygen exchange between the cerium oxide-based catalyst and the oxygen-containing gas molecules (mainly $\mathrm{O}_{2}$ ) [17]. In spite of this active oxygen-based reaction mechanism is well understood and that active oxygen species are expected to be much more oxidizing than $\mathrm{NO}_{2}$, better soot combustion capacity than that of commercial platinum-based catalysts has not been reported so far. The main handicap of this highly efficient active oxygen-based reaction mechanism is the poor soot-catalyst contact, since most active oxygen species, which are postulated to be 
oxygen radicals, recombine rapidly to each other and yield $\mathrm{O}_{2}$ again before they reach the carbon surface.

In this study, $\mathrm{Pr}$ or $\mathrm{Zr}$ doped ceria catalysts of several compositions have been prepared by different methods, and soot combustion experiments have been performed with soot and catalyst solid particles mixed in the so-called "loose contact" mode [18]. It is mandatory to perform the experiments under realistic reaction conditions - gas mixture with both $\mathrm{NOx}$ and $\mathrm{O}_{2}$ and poor soot-catalyst contact - in order to obtain results with practical relevance.

\section{2.- Experimental details}

\subsection{Catalysts used}

Two commercial catalysts were used as reference materials. A 1 wt. \% $\mathrm{Pt} / \mathrm{Al}_{2} \mathrm{O}_{3}$ catalyst was supplied by Sigma-Aldrich (BET surface area $160 \mathrm{~m}^{2} / \mathrm{g}$ ) and a $\mathrm{Ce} 0.8 \mathrm{Zr}_{0.2} \mathrm{O}_{2}$ catalyst was supplied by Rhodia and was used after calcination at either 500 or $800{ }^{\circ} \mathrm{C}$.

$\mathrm{Ce}_{\mathrm{x}} \mathrm{Pr}_{1-\mathrm{x}} \mathrm{O}_{2}(\mathrm{x}=0.8$ or 0.5$)$ and $\mathrm{Ce}_{0.8} \mathrm{Zr}_{0.2} \mathrm{O}_{2}$ mixed oxides were prepared by reversed microemulsion, and the $\operatorname{Pr}$ and $\mathrm{Zr}$ loading was the optimum for this application according to previous studies (20 molar \% for zirconium [19] and 50 molar \% for praseodymium [14]). Reference catalysts were also prepared by coprecipitation with the same composition than those prepared by microemulsion and, for few selected compositions, mixed oxides were also prepared by nitrates calcination.

The Ce-Pr mixed oxides were prepared with the $3^{+}$cation precursors $\mathrm{Ce}\left(\mathrm{NO}_{3}\right)_{3} \cdot 6 \mathrm{H}_{2} \mathrm{O}$ (Aldrich, 99.99\%) and $\operatorname{Pr}\left(\mathrm{NO}_{3}\right)_{3} \cdot 6 \mathrm{H}_{2} \mathrm{O}$ (Aldrich, 99.9\%) and the $\mathrm{Ce}-\mathrm{Zr}$ mixed oxides with the $4+$ cation precursors $\left(\mathrm{NH}_{4}\right)_{2} \mathrm{Ce}\left(\mathrm{NO}_{3}\right)_{6}$ (Panreac, 99.0\%) and 
$\mathrm{ZrO}\left(\mathrm{NO}_{3}\right)_{2} \cdot \mathrm{H}_{2} \mathrm{O}$ (Aldrich, $\mathrm{x} \approx 6$, technical grade). The selection of cation precursors of similar charge favors homogeneous coprecipitation [20].

Catalysts preparation by reversed microemulsion method consisted of dissolving the required amounts of each precursor in water, and a microemulsion in n-heptane was prepared including Triton X-100 surfactant (polioxiethylene (9) 4 -(1,1,3,3,tetramethybutyl) phenyl ether) and hexanol as co-surfactant. For instance, in a typical synthesis of $2 \mathrm{~g}$ of $\mathrm{Ce}_{0.5} \mathrm{Pr}_{0.5} \mathrm{O}_{2}, 2.6 \mathrm{~g}$ of the Ce precursor $+2.6 \mathrm{~g}$ of the Pr precursor were dissolved in $20 \mathrm{ml}$ of water, and $114 \mathrm{~g}$ of n-heptane, $37 \mathrm{~g}$ of Triton X-100 and $29 \mathrm{~g}$ of hexanol were used. A similar microemulsion was prepared but with tetramethylammonium hydroxide (6.8 $\mathrm{g}$ for a typical synthesis of $2 \mathrm{~g}$ of catalysts) instead of the metal precursors. Both microemulsions were mixed and vigorously stirred for 24 hours and, after precipitation, were centrifuged at $3000 \mathrm{rev} / \mathrm{min}$ for 6 minutes and the liquid phases were decanted. The solids obtained were washed with ethanol, dried at $110^{\circ} \mathrm{C}$ and calcined at $500{ }^{\circ} \mathrm{C}$ for $1 \mathrm{~h}$. mixture of the metal precursors at $500{ }^{\circ} \mathrm{C}$ for $1 \mathrm{~h}$.

Table 1 includes details about the synthesis and characterization of all catalysts prepared in this study. 


\subsection{Catalysts characterization.}

Powder XRD patterns were recorded in a Bruker D8 advance diffractrometer, using $\mathrm{CuK} \alpha$ radiation. Diffractograms were registered between 10 and $60^{\circ}(2 \theta)$ with a step of $0.02^{\circ}$ and a time per step of $3 \mathrm{~s}$.

$\mathrm{N}_{2}$ adsorption isotherms were obtained at $-196{ }^{\circ} \mathrm{C}$ in an automatic volumetric system (Autosorb-6, Quantachrome). The catalysts were degassed at $250{ }^{\circ} \mathrm{C}$ for 4 hours under vacuum before the adsorption measurements. The BET surface areas were determined and the particle sizes were estimated from the BET surface area values assuming spherical shape of the particles and a density of $7.135 \mathrm{~g} / \mathrm{cm}^{3}$.

Raman spectra were recorded in a Bruker RFS 100/S Fourier Transform Raman Spectrometer with a variable power Nd:YAG laser source (1064 nm). 64 scans at 85 $\mathrm{mW}$ laser power (70 $\mathrm{mW}$ on the sample) were recorded and no heating of the sample was observed under these conditions.

Temperature Programmed Reductions with $\mathrm{H}_{2}$ (H2-TPR) were carried out in a Micromeritics Pulse ChemiSorb 2705 device, consisting of a tubular quartz reactor coupled to a TCD detector. The reducing gas used was $5 \% \mathrm{H}_{2}$ in Ar, with a flow rate of $35 \mathrm{ml} / \mathrm{min}$. The temperature range explored was from room temperature to $1000{ }^{\circ} \mathrm{C}$ at a heating rate of $10^{\circ} \mathrm{C} / \mathrm{min}$. Before the reduction, the catalysts were pretreated in situ at $500{ }^{\circ} \mathrm{C}$ for $1 \mathrm{~h}$ with a gas flow of $5 \% \mathrm{O}_{2} / \mathrm{He}$.

\subsection{Catalytic tests.}

Catalytic tests were performed in a tubular quartz reactor coupled to specific NDIR-UV gas analyzers for $\mathrm{CO}, \mathrm{CO}_{2}, \mathrm{NO}, \mathrm{NO}_{2}$ and $\mathrm{O}_{2}$ monitoring. $20 \mathrm{mg}$ of soot and $80 \mathrm{mg}$ of the selected catalyst were mixed in the so-called loose contact conditions and 
diluted with SiC to avoid pressure drop and favor heat transfer. The model soot used in this study is a carbon black by Evonik-Degussa GmbH (Printex U). The gas mixture used contained either $500 \mathrm{ppm} \mathrm{NOx} / 5 \% \mathrm{O}_{2} / \mathrm{N}_{2}$ or $5 \% \mathrm{O}_{2} / \mathrm{N}_{2}$, and the gas flow was fixed at $500 \mathrm{ml} / \mathrm{min}\left(\mathrm{GHSV}=30000 \mathrm{~h}^{-1}\right)$. Temperature Programmed reactions from room temperature until $700{ }^{\circ} \mathrm{C}$ at $10{ }^{\circ} \mathrm{C} / \mathrm{min}$ were carried out. Blank experiments were also conducted under $\mathrm{NOx} / \mathrm{O}_{2}$ only with the catalysts (no soot), in order to analyze the $\mathrm{NO}_{2}$ production capacity of the oxides.

\section{3.- Results and discussion.}

\subsection{Catalysts characterization.}

The catalysts were characterized by XRD and all catalysts showed the typical fluorite structure of ceria-based oxides. The X-ray diffractograms are not shown for the sake of brevity. The cell parameters and crystal sizes were determined with the (111) peak and the values obtained are compiled in Table 1 . All ceria-based catalysts prepared present particle sizes between 6 and $31 \mathrm{~nm}$, which were calculated from the $\mathrm{N}_{2}$ adsorption isotherms. The smallest particles and the highest BET surface areas were obtained by the microemulsion method, and the values reached by $\mathrm{Ce}_{0.5} \mathrm{Pr}_{0.5} \mathrm{O}_{2}$ are the highest ever reported for this material (more details and references are included below).

The cell parameters obtained for Zr-containing ceria catalysts are lower than the typical value assigned to pure ceria $(\sim 0.5424 \mathrm{~nm})$, which is consistent with the substitution of the parent $\mathrm{Ce}^{4+}$ cations $(0.097 \mathrm{~nm})$ by smaller $\mathrm{Zr}^{4+}$ cations $(0.084 \mathrm{~nm})$. On the contrary, the cell parameters obtained with the Pr-containing ceria catalysts are equal or higher to the pure ceria value, because the size of $\mathrm{Ce}^{4+} / \mathrm{Ce}^{3+}$ and $\mathrm{Pr}^{4+} / \mathrm{Pr}^{3+}$ cations (0.097/0.114 and 0.096/0.113 nm, respectively) is almost equal. The higher cell 
parameters obtained in some cases upon Pr doping must be attributed to the presence of more $3+$ cations, since $\operatorname{Pr}^{4+}$ is reduced more easily than $\mathrm{Ce}^{4+}$.

These features of the ceria-based catalysts are confirmed by Raman characterization included in Figure 1. All Raman spectra showed the typical $F_{2 g}$ band of the ceria fluorite structure with maxima at $442-477 \mathrm{~cm}^{-1}$. Note that the intensity of the Raman spectra has been normalized with regard to the maximum intensity of the $\mathrm{F}_{2 \mathrm{~g}}$ band, because the fluorescence produced by praseodymium significantly affects the intensity. Since the intensity is not only related to the structural order of the oxides, the information about such structure is obtained from the bands position. The typical position of the $\mathrm{F}_{2 \mathrm{~g}}$ band is $464 \mathrm{~cm}^{-1}$ for pure ceria (dotted line in the Figure 1), and zirconium doping shifts the position to higher Raman shifts while praseodymium shifts the position to lower values. In accordance with the cell parameter values in Table 1, the shift in the position of the $\mathrm{F}_{2 \mathrm{~g}}$ Raman band is due to the substitution of $\mathrm{Ce}^{4+}$ cations by smaller and larger $\mathrm{Zr}^{4+}$ and $\mathrm{Pr}^{3+}$ cations, respectively.

The small band or shoulder observed in the $515-600 \mathrm{~cm}^{-1}$ range is assigned to the creation of oxygen vacancies on the oxides. The intensity of this band (after normalization of the signals intensity) is highest for the ceria catalysts with highest praseodymium content $\left(\mathrm{Ce}_{0.5} \mathrm{Pr}_{0.5} \mathrm{O}_{2}\right)$, in agreement with the easy reducibility of $\mathrm{Pr}^{4+}$ to $\operatorname{Pr}^{3+}$

Additional information about the catalysts reducibility is obtained by $\mathrm{H}_{2}$ Temperature Programmed Reduction (Figure 2). $\mathrm{H}_{2}$ consumption is mainly attributed to $\mathrm{Ce}^{4+}$ and $\mathrm{Pr}^{4+}$ reduction, because $\mathrm{Zr}^{4+}$ cannot be reduced under these conditions, and as a general trend, the position of the bands confirms that praseodymium doping improves the ceria-based catalysts reducibility with regard to zirconium doping. For all 
compositions compared, the reducibility of the oxides prepared by coprecipitation is higher to that of the counterpart oxides prepared by microemulsion.

\subsection{Catalytic tests.}

Figure 3 shows the soot conversion curves obtained with several representative catalysts in gas mixtures with $\mathrm{NOx}+\mathrm{O}_{2}+\mathrm{N}_{2}$ (Figure 3a) and $\mathrm{O}_{2}+\mathrm{N}_{2}$ (Figure 3b). For the sake of brevity, not all catalysts prepared and evaluated in this study have been included in Figure 3, but all curves can be found in the Supplementary Information (Figure 1SI). Figure 3 includes the soot conversion curves obtained with the most active catalyst prepared ( $\mathrm{Ce}_{0.5} \mathrm{Pr}_{0.5} \mathrm{O}_{2}$ (microemulsion)) together with reference curves obtained with a commercial $\mathrm{Pt} / \mathrm{Al}_{2} \mathrm{O}_{3}$ catalyst, a $\mathrm{Ce}_{0.5} \mathrm{Pr} 0.5 \mathrm{O}_{2}$ catalyst prepared by a conventional coprecipitation method and the uncatalyzed curve.

The catalyst referred to as $\mathrm{Ce}_{0.5} \mathrm{Pr}_{0.5} \mathrm{O}_{2}$ (microemulsion) is more active than the reference $\mathrm{Pt} / \mathrm{Al}_{2} \mathrm{O}_{3}$ catalyst, being the most active soot combustion catalyst ever reported among those tested under realistic conditions (presence of NOx and poor sootcatalyst contact) if catalysts forming highly volatile species are ruled out. The $\mathrm{Ce}_{0.5} \mathrm{Pr}_{0.5} \mathrm{O}_{2}$ (microemulsion) catalyst also has the highest surface area and the smallest particle size ever reported (125 $\mathrm{m}^{2} / \mathrm{g}$ and $7 \mathrm{~nm}$ respectively) for this material. Representative surface areas reported by other authors for comparable materials are 35 and $20 \mathrm{~m}^{2} / \mathrm{g}$ for $\mathrm{Ce}_{0.8} \mathrm{Pr}_{0.2} \mathrm{O}_{2}$ and $\mathrm{Ce}_{0.5} \mathrm{Pr}_{0.5} \mathrm{O}_{2}$, respectively, prepared by ammonia coprecipitation [21], $40 \mathrm{~m}^{2} / \mathrm{g}$ for $\mathrm{Ce} 0.8 \mathrm{Pr} 0.2 \mathrm{O}_{2}$ also prepared by ammonia coprecipitation [22], $48 \mathrm{~m}^{2} / \mathrm{g}$ for $\mathrm{Ce}_{0.8} \mathrm{Pr}_{0.2} \mathrm{O}_{2}$ prepared by microwave-assisted solution combustion [23], and $92 \mathrm{~m}^{2} / \mathrm{g}$ for $\mathrm{Ce}_{0.8} \mathrm{Pr}_{0.2} \mathrm{O}_{2}$ prepared by citrate precipitation [24]. As far as we know, the highest surface area ever reported for a Ce-Pr mixed oxide is $150 \mathrm{~m}^{2} / \mathrm{g}$ for $\mathrm{Ce}_{0.9} \mathrm{Pr}_{0.1} \mathrm{O}_{2}$ prepared by surfactant-assisted hydrothermal treatment, but this area 
217 decreased significantly for mixed oxides with higher praseodymium concentration (90 $\mathrm{m}^{2} / \mathrm{g}$ for $\left.\mathrm{Ce}_{0.5} \mathrm{Pr}_{0.5} \mathrm{O}_{2}\right)$ [25].

For a broader comparison of the catalytic behavior, Table 2 compiles the T50\% temperature, which is the temperature required to achieve $50 \%$ soot combustion, obtained in similar experiments to those shown in Figure 3a with representative catalysts of different nature. Metal oxides where the cation can hardly accomplish redox cycles $\left(\mathrm{TiO}_{2}, \mathrm{ZrO}_{2}, \mathrm{MnO}\right.$ and $\mathrm{MnO}_{2}$ ) show the lowest activities, followed by catalysts with non-noble transition metal cations that are able to accomplish redox cycles (Co and $\mathrm{Cu}$ catalysts and $\left.\mathrm{Mn}_{3} \mathrm{O}_{4}\right)$. activity, but only the Ce-Pr mixed oxides prepared in the current study by the microemulsion method are able to outperform the behavior of the platinum catalysts.

The mechanistic arguments to explain the high catalytic activity of the CexPr1${ }_{x} \mathrm{O}_{2}(\mathrm{x}=0.8$ or 0.5$)$ mixed oxides prepared in this study by the microemulsion method have been analyzed and relevant information is obtained from combustion experiments performed in the $\mathrm{O}_{2}+\mathrm{N}_{2}$ gas mixture (Figure $3 \mathrm{~b}$ ). The activity of the platinum catalyst is very low in the absence of NOx, because this catalyst mainly accelerates soot combustion by the $\mathrm{NO}_{2}$-assisted mechanism, that is, oxidizes $\mathrm{NO}$ to $\mathrm{NO}_{2}$ and $\mathrm{NO}_{2}$ initiates soot combustion, as previously described. This is supported by the $\mathrm{NO}_{2}$ profiles obtained in the absence of soot, which are included in Figure 4, where the highest NO oxidation capacity of the platinum catalyst is clearly evidenced. Therefore, if NOx is not available, the $\mathrm{NO}_{2}$-assisted soot combustion mechanism is not feasible. combustion activity even in the absence of NOx (and the most active catalyst is 
$241 \mathrm{Ce}_{0.5} \operatorname{Pr}_{0.5} \mathrm{O}_{2}$ (microemulsion)) due to the important participation of the active oxygen-

242 based mechanism, that is, ceria catalysts exchange oxygen with the $\mathrm{O}_{2}$ molecules and

243 deliver highly reactive oxygen species to soot [17]. Additionally, in spite of ceria

244 catalysts being less active than platinum for NO oxidation (see Figure 4), they are also

245 able to promote $\mathrm{NO}_{2}$ formation in a certain extent, and therefore both the active oxygen

246 and $\mathrm{NO}_{2}$-assisted mechanisms contribute simultaneously (and synergistically) to soot

247 combustion. That is why the soot combustion activity of the ceria catalysts is higher in

248 the $\mathrm{NOx}+\mathrm{O}_{2}+\mathrm{N}_{2}$ gas mixture (Figure 3a) than in $\mathrm{O}_{2}+\mathrm{N}_{2}$ (Figure 3b).

These soot combustion experiments performed with $\mathrm{NOx}+\mathrm{O}_{2}+\mathrm{N}_{2}$ (Figure 3a)

and $\mathrm{O}_{2}+\mathrm{N}_{2}$ (Figure $3 \mathrm{~b}$ ) gas mixtures, and the $\mathrm{NO}_{2}$ profiles obtained in similar experiments performed without soot (Figure 4), have demonstrated the important role of the active oxygen mechanism in the ceria-catalyzed combustion of soot, but this was in somehow already known, and additional information is required to explain the best performance of the $\mathrm{Ce}_{0.5} \mathrm{Pr}_{0.5} \mathrm{O}_{2}$ (microemulsion) catalyst.

As previously mentioned, the active oxygen species are unstable and will recombine to each other yielding $\mathrm{O}_{2}$ if they do not reach the carbon surface. For this reason, the size of the ceria-based catalysts particles plays a key role in the combustion of soot, since the lower the ceria particle size, the higher the number of contact points with soot and the easier the active oxygen transfer from ceria to soot. This concept is evidenced in Figure 5, where the T50\% temperature obtained in soot combustion experiments performed in a $\mathrm{NOx}+\mathrm{O}_{2}+\mathrm{N}_{2}$ gas mixture is plotted against the particle size of two series of ceria-based catalysts. The ceria catalyst formulations selected are the most active for Ce-Zr mixed oxide catalysts (with 20 molar \% zirconium) [19] and Ce-Pr mixed oxides catalysts (with 50 molar \% praseodymium) [14], according to previous studies. The different catalysts of each composition have been prepared 
following different synthesis procedures (calcination of a physical mixture of nitrates, coprecipitation, and reverse microemulsion) and a commercial $\mathrm{Ce}-\mathrm{Zr}$ mixed oxide calcined at 500 and $800{ }^{\circ} \mathrm{C}$ has been also included.

Figure 5 shows that the Ce-Pr mixed oxides are more active than the Ce- $\mathrm{Zr}$ mixed oxides, and linear relationships between the particle size of the catalysts and the combustion of soot were obtained for each catalyst composition, the lower the ceria size the lower the soot combustion temperature. Each formulation follows a different linear trend because the composition determines the intrinsic activity of the mixed oxide (the active oxygen production) and the particle size the transfer of such active oxygen to soot.

Eighteen $\mathrm{Ce}_{0.76} \mathrm{Zr}_{0.24 \mathrm{O}_{2}}$ soot combustion catalysts were prepared by different methods in a previous study, and the main soot combustion mechanism was based on the catalytic oxidation of NO for most catalysts [30]. In that case, a relationship between catalyst surface area and soot combustion was found for BET areas lower than $90 \mathrm{~m}^{2} / \mathrm{g}$. However, the increase of the surface area above this threshold had not an additional benefit on soot combustion, and it was concluded that T50\% temperatures below $490{ }^{\circ} \mathrm{C}$ cannot be obtained with these Ce-Zr catalysts. The Ce-Pr mixed oxide nanoparticles prepared in the current study are able to obtain T50\% temperatures below $490{ }^{\circ} \mathrm{C}$ because of the relevant contribution of the active oxygen-assisted soot combustion mechanism.

As a summary, it can be concluded that both the ceria-based catalyst composition (nature and amount of dopant) and the particle size play key roles in the combustion of soot. The composition determines the production of active oxygen and the particle size the transfer of active oxygen from catalyst to soot. The optimization of 
both parameters (composition of the ceria-based catalyst and size of the particles) has allowed us to prepare soot combustion catalysts that outperform the behavior of platinum-catalysts even under NOx-containing gas mixtures where commercial platinum catalysts are usually the most active ones.

\section{4.- Conclusions.}

A $\mathrm{Ce}_{0.5} \mathrm{Pr}_{0.5} \mathrm{O}_{2}$ mixed oxide has been prepared with the highest surface area and smallest particle size ever reported $\left(125 \mathrm{~m}^{2} / \mathrm{g}\right.$ and $7 \mathrm{~nm}$ respectively), being also the most active diesel soot combustion catalyst ever reported among those tested under realistic conditions if catalysts forming highly volatile species are ruled out. Both the ceria-based catalyst composition (nature and amount of dopant) and the particle size play key roles in the combustion of soot. The composition determines the production of active oxygen and the particle size the transfer of active oxygen from catalyst to soot. The optimization of both parameters (composition of the ceria-based catalyst and size of the particles) has allowed preparing soot combustion catalysts that outperform the behavior of platinum-catalysts even under NOx-containing gas mixtures where commercial platinum catalysts are usually the most active ones.

\section{Acknowledgments}

The authors thank the financial support of Generalitat Valenciana (Project PROMETEOII/2014/010), the Spanish Ministry of Economy and Competitiveness (Project CTQ2012-30703), and the UE (FEDER funding). 
[1] M. V. Twigg, Appl. Catal. B 70 (2007) 2-15.

[2] B. Frank, M. E. Schuster, R. Schlogl, D. S. Su, Angew. Chem. Int. Ed. 52 (2013) $2673-267$.

[3] R. A. Kerr, Science 339 (2013) 382.

[4] J. Tollefson, Nature 493 (2013) 454.

[5] B.A.A.L.Van Setten, M. Makkee, J.A. Moulijn, Catal. Rev. Sci. Eng. 43 (2001) 489-564.

[6] D. Fino, V. Specchia, Powd. Technol. 180 (2008) 64-73.

[7] A. Setiabudi, N.K. Allaart, M. Makkee, J. A. Moulijn, Appl. Catal. B 60 (2005) 233-243.

[8] G. Mul, J.P. Neeft, F. Kapteijn, M. Makkee, J.A. Moulijn, Appl. Catal. B 6 (1995) 339-352.

[9] K. Villani, C. E. A. Kirschhock, D. Liang, G. Van Tendeloo, J. A. Martens, Angew. Chem. Int. Ed. 45 (2006) 3106 -3109.

[10] H.S. Gandhi, G.W. Graham, R.W. McCabe, J. Catal. 216 (2003) 433-442.

[11] B.J. Cooper, H.J. Jung, J.E. Thoss (Johnson Matthey) US Patent 1999, request number US07/193,529; publication number US4902487 A.

[12] K. Krishna, A. Bueno-López, M. Makkee, J.A. Moulijn, Appl. Catal. B 75 (2007) 210-220.

[13] E. Aneggi, C. de Leitenburg, G. Dolcetti, A. Trovarelli, Catal. Today 114 (2006) 40-47.

[14] M.L. Pisarello, V. Milt, M.A. Peralta, C.A. Querini, E.E. Miró, Catal. Today 75 (2002) 465-470.

[15] L. Katta, P. Sudarsanam, G. Thrimurthulu, B.M. Reddy, Appl. Catal. B 101 (2010) 101-108.

[16] E. Kockrick, C. Schrage, A. Grigas, D. Geiger, S. Kaskel J. Sol. State Chem. 181 (2008) 1614-1620.

[17] N. Guillén-Hurtado, A. García-García, A. Bueno-López. J. Catal. 299 (2013) 181-187.

[18] B.A.A.L. Van Setten, J.M. Schouten, M. Makkee, J.A. Moulijn, Appl. Catal. B 28 (2000) 253-257.

[19] I. Atribak, A. Bueno-López, A. García-García, J. Catal. 259 (2008) 123-132. 
[20] N. Guillén-Hurtado, I. Atribak, A. Bueno-López, A. García-García. J Molec. Catal. A 323 (2010) 52-58

[21] S. Imamura, J.-ichi Tadani, Y. Saito, Y. Okamotoa, H. Jindai, C. Kaito, Appl. Catal. A 201 (2000) 121-127.

[22] S. Bernal, G. Blanco, M. A. Cauqui, A. Martín, J. M. Pintado, A. Galtayries, R. Sporken, Surf. Interface Anal. 30 (2000) 85-89.

[23] L. H. Reddy, G. K. Reddy, D. Devaiah, B. M. Reddy, Appl. Catal. A 445 (2012) 297-305.

[24] G.-Q. Xie, M.-F. Luo, M. He, P. Fang, J.-M. Ma, Y.-F. Ying, Z.-L. Yan. J. Nanopar. Res. 9 (2007) 471-478.

[25] S. Somacescu, V. Parvulescu, J. M. Calderon-Moreno, S.-H. Suh, P. Osiceanu, B.-L. Su, J. Nanopart. Res. 14 (2012) 885-902.

[26] I. Atribak, I. Such-Basáñez, A. Bueno-López, A. García-García, J. Catal. 250 (2007) 75-84.

[27] I. Atribak, A. Bueno-López, A. García-García, P. Navarro, D. Frías, M. Montes, Appl. Catal. B 93 (2010) 267-273.

[28] M. Zawadzki, W. Walerczyk, F.E. López-Suárez, M.J. Illán-Gómez, A. BuenoLópez, Catal. Commun. 12 (2011) 1238-1241.

[29] T. Sánchez, F.B. Gebretsadik, P. Salagre, Y. Cesteros, N. Guillén-Hurtado, A. García-García, A. Bueno-López, Appl. Clay Sci. 77-78 (2013) 40-45.

[30] I. Atribak, A. Bueno-Lopez, A. Garcia-Garcia, Top. Catal. 52 (2009) 20882091.

[31] I. Atribak, A. Bueno-López, A. García-García, J. Catal. 259 (2008) 123-132. 


\section{Figure Captions}

371 Figure 1. Raman spectra of representative ceria-based catalysts calcined at $500{ }^{\circ} \mathrm{C}$.

372 Figure 2. Temperature Programmed Reduction with $\mathrm{H}_{2}$ of ceria-based catalysts 373 calcined at $500^{\circ} \mathrm{C}$.

374 Figure 3. Soot combustion curves in $\mathrm{NOx}+\mathrm{O}_{2}+\mathrm{N}_{2}$ (a) and $\mathrm{O}_{2}+\mathrm{N}_{2}$ (b) either 375 uncatalysed or with home-made $\mathrm{Ce}_{0.5} \mathrm{Pr}_{0.5} \mathrm{O}_{2}$ and commercial platinum catalysts.

376 Figure 4. $\mathrm{NO}_{2}$ production by catalytic oxidation of $\mathrm{NO}$ in a $\mathrm{NOx}+\mathrm{O}_{2}+\mathrm{N}_{2}$ gas 377 mixture.

378 Figure 5. Relationship between soot combustion capacity in a $\mathrm{NOx}+\mathrm{O}_{2}+\mathrm{N}_{2}$ gas 379 mixture and particle size/surface area of ceria-based catalysts. All catalysts were 380 calcined at $500{ }^{\circ} \mathrm{C}$, otherwise indicated. 
Table 1. Details about catalysts preparation and characterization.

\begin{tabular}{|c|c|c|c|c|c|}
\hline $\begin{array}{l}\text { Catalyst } \\
\text { composition }\end{array}$ & $\begin{array}{c}\text { Preparation } \\
\text { method }^{[a]}\end{array}$ & $\begin{array}{c}\mathrm{T} 50 \%{ }^{[\mathrm{b}]} \\
\left({ }^{\circ} \mathrm{C}\right)\end{array}$ & $\begin{array}{l}\text { Cell parameter } \\
\text { (nm) }\end{array}$ & $\begin{array}{c}\mathrm{BET} \\
\left(\mathrm{m}^{2} / \mathrm{g}\right)\end{array}$ & $\begin{array}{c}\text { Particle } \\
\text { size }(n m)\end{array}$ \\
\hline $\mathrm{Ce}_{0.8} \mathrm{Zr}_{0.2} \mathrm{O}_{2}$ & Microemulsion & 484 & 0.5366 & 145 & 6 \\
\hline $\mathrm{Ce}_{0.8} \mathrm{Zr}_{0.2} \mathrm{O}_{2}$ & Coprecipitation & 502 & 0.5369 & 57 & 15 \\
\hline $\mathrm{Ce}_{0.8} \mathrm{Zr}_{0.2} \mathrm{O}_{2}$ & Commercial & 491 & 0.5333 & 113 & 7 \\
\hline $\mathrm{Ce}_{0.8} \mathrm{Zr}_{0.2} \mathrm{O}_{2}$ & Commercial $\left(800^{\circ} \mathrm{C}\right)$ & 516 & 0.5351 & 48 & 18 \\
\hline $\mathrm{Ce}_{0.5} \mathrm{Pr}_{0.5} \mathrm{O}_{2}$ & Microemulsion & 444 & 0.5446 & 125 & 7 \\
\hline $\mathrm{Ce} 0.5 \mathrm{Pr}_{0.5} \mathrm{O}_{2}$ & Coprecipitation & 485 & 0.5433 & 27 & 31 \\
\hline $\mathrm{Ce}_{0.5} \mathrm{Pr}_{0.5} \mathrm{O}_{2}$ & Nitrates calcination & 477 & 0.5424 & 37 & 23 \\
\hline $\mathrm{Ce}_{0.8} \mathrm{Pr}_{0.2} \mathrm{O}_{2}$ & Microemulsion & 459 & 0.5424 & 120 & 7 \\
\hline $\mathrm{Ce}_{0.8} \mathrm{Pr}_{0.2} \mathrm{O}_{2}$ & Coprecipitation & 502 & 0.5424 & 70 & 12 \\
\hline
\end{tabular}

387

[a] The catalysts were calcined at $500{ }^{\circ} \mathrm{C}$, otherwise indicated.

[b] Temperature required to achieve $50 \%$ soot combustion in experiments performed with a 500 ppm NOx $+5 \mathrm{O}_{2}+\mathrm{N}_{2}$ mixture.

Table 2. Comparison of diesel soot combustion catalysts of different nature tested in realistic laboratory conditions ("loose" soot-catalyst contact and $\mathrm{NOx}+\mathrm{O}_{2}+\mathrm{N}_{2}$ gas mixture).

\begin{tabular}{|c|c|c|}
\hline Catalyst & $\mathrm{T} 50 \%\left({ }^{\circ} \mathrm{C}\right)^{[\mathrm{a}]}$ & Reference \\
\hline No catalyst & 607 & [This article, 26, 27] \\
\hline $\mathrm{MnO}$ & 601 & [27] \\
\hline $\mathrm{MnO}_{2}$ & 597 & [27] \\
\hline $\mathrm{ZrO}_{2}$ & 592 & [26] \\
\hline $\mathrm{TiO}_{2}$ & 593 & [62] \\
\hline $\mathrm{CoAl}_{2} \mathrm{O}_{4}$ spinel & 563 & [28] \\
\hline $\mathrm{Cu} /$ hectorite & 560 & [29] \\
\hline $\mathrm{Mn}_{3} \mathrm{O}_{4}$ & 510 & [27] \\
\hline $\mathrm{Ce}_{0.8} \mathrm{Pr}_{0.2} \mathrm{O}_{2}$ (coprecipitation) & 502 & [This article] \\
\hline $\mathrm{Ce}_{0.8} \mathrm{Zr}_{0.2} \mathrm{O}_{2}$ (commercial) & 488 & {$[30,21]$} \\
\hline $\mathrm{Ce}_{0.8} \mathrm{Zr}_{0.2} \mathrm{O}_{2}$ (microemulsion) & 484 & [This article] \\
\hline $\mathrm{Ce}_{0.5} \mathrm{Pr}_{0.5} \mathrm{O}_{2}$ (coprecipitation) & 484 & [This article] \\
\hline Cryptomelane & 481 & [27] \\
\hline $1 \% \mathrm{Pt} / \mathrm{CoAl}_{2} \mathrm{O}_{4}$ & 478 & [28] \\
\hline $1 \% \mathrm{Pt} / \mathrm{Al}_{2} \mathrm{O}_{3}$ (commercial) & 475 & [This article] \\
\hline $\mathrm{Ce}_{0.8} \mathrm{Pr}_{0.2} \mathrm{O}_{2}$ (microemulsion) & 459 & [This article] \\
\hline $\mathrm{Ce}_{0.5} \mathrm{Pr}_{0.5} \mathrm{O}_{2}$ (microemulsion) & 444 & [This article] \\
\hline
\end{tabular}


[a] $\mathrm{T} 50 \%$ is the temperature required to achieve $50 \%$ soot combustion, the lower the better. According to reproducibility experiments, the error in the estimation of the

403 T50\% temperature is $\pm 2{ }^{\circ} \mathrm{C}$. 


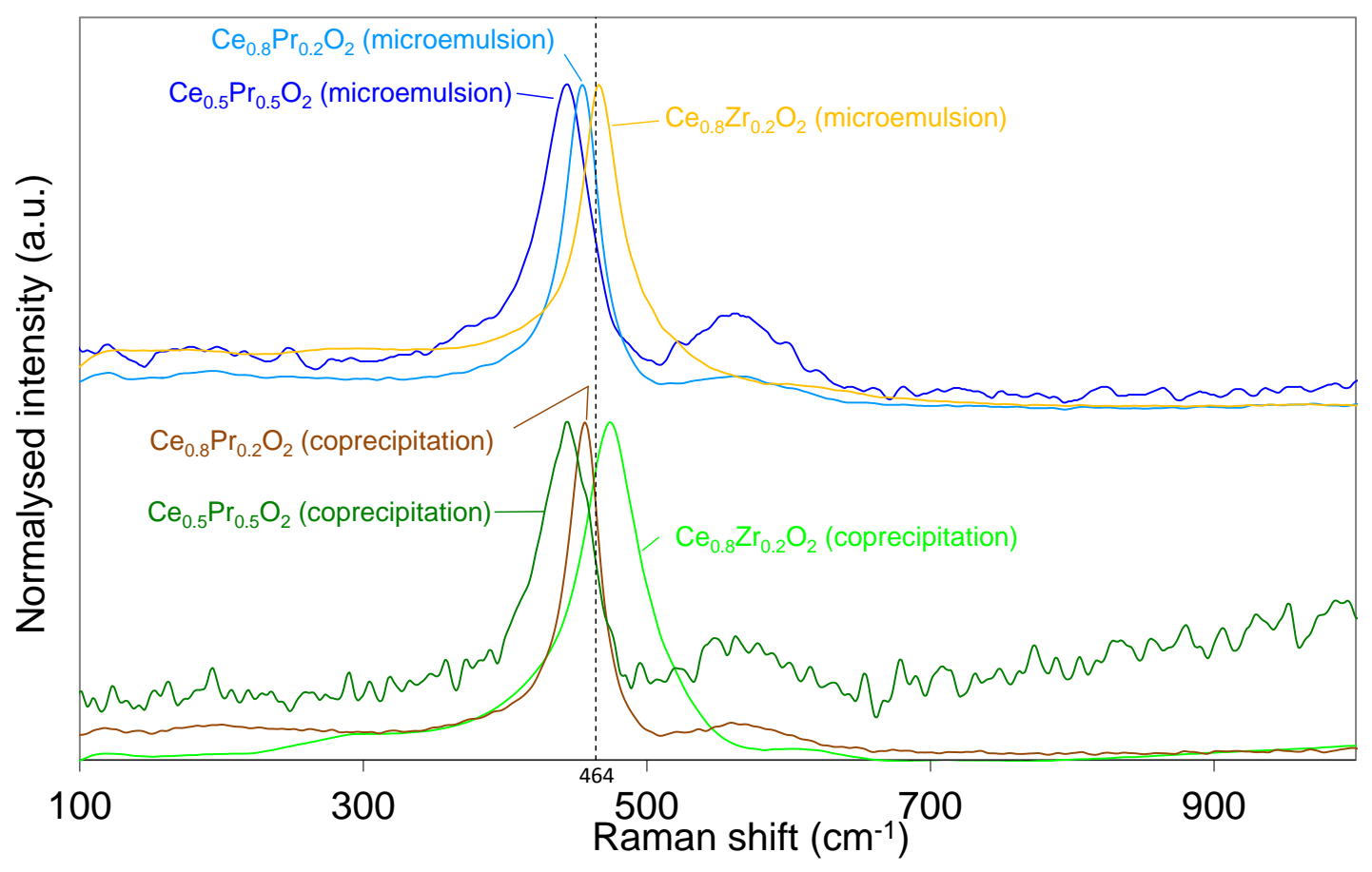

407

408

409

410

411 
Figure 2

414

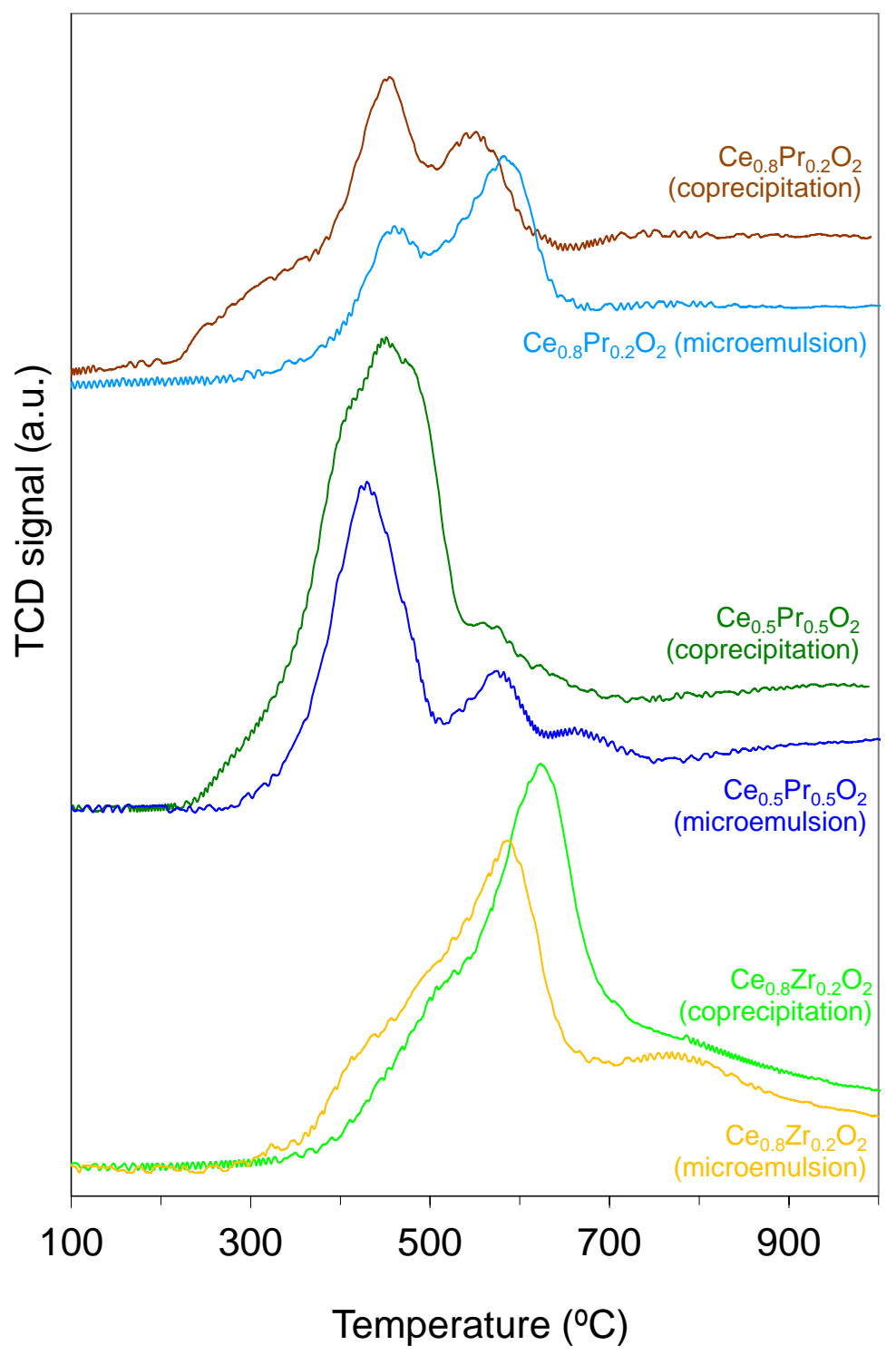

415

416

417 
Figure 3
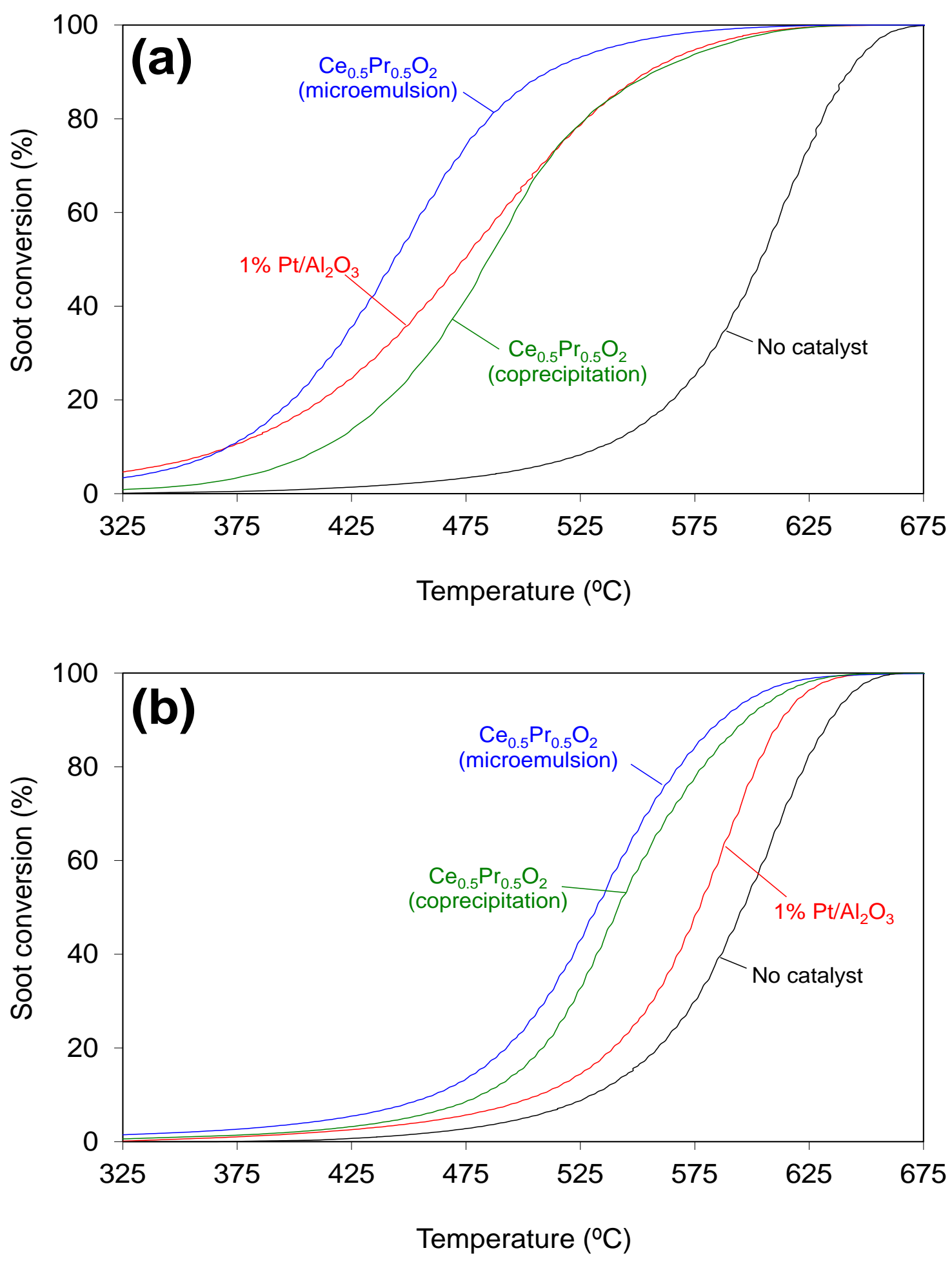


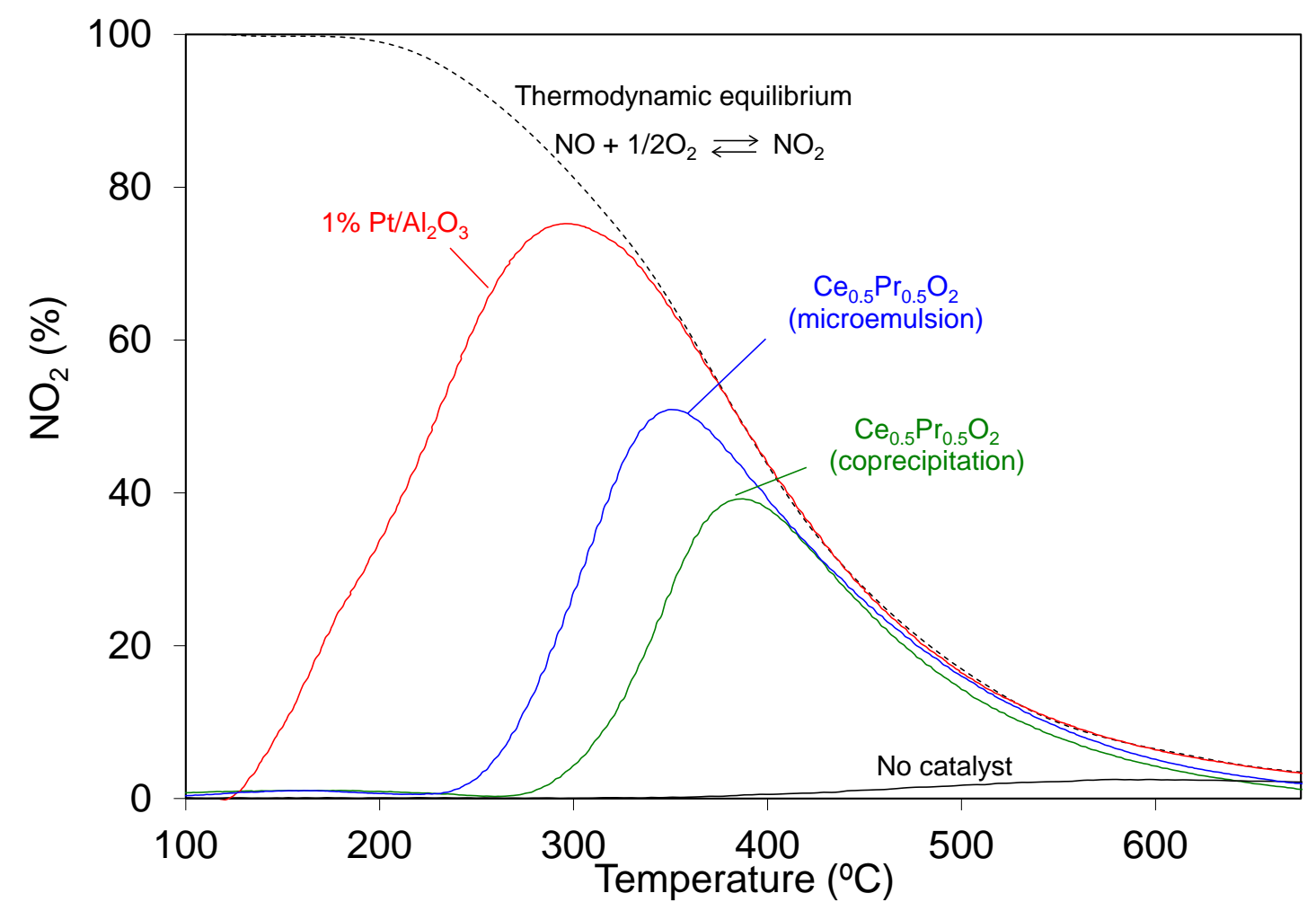

421 
Catalyst surface area $\left(\mathrm{m}^{2} / \mathrm{g}\right)$

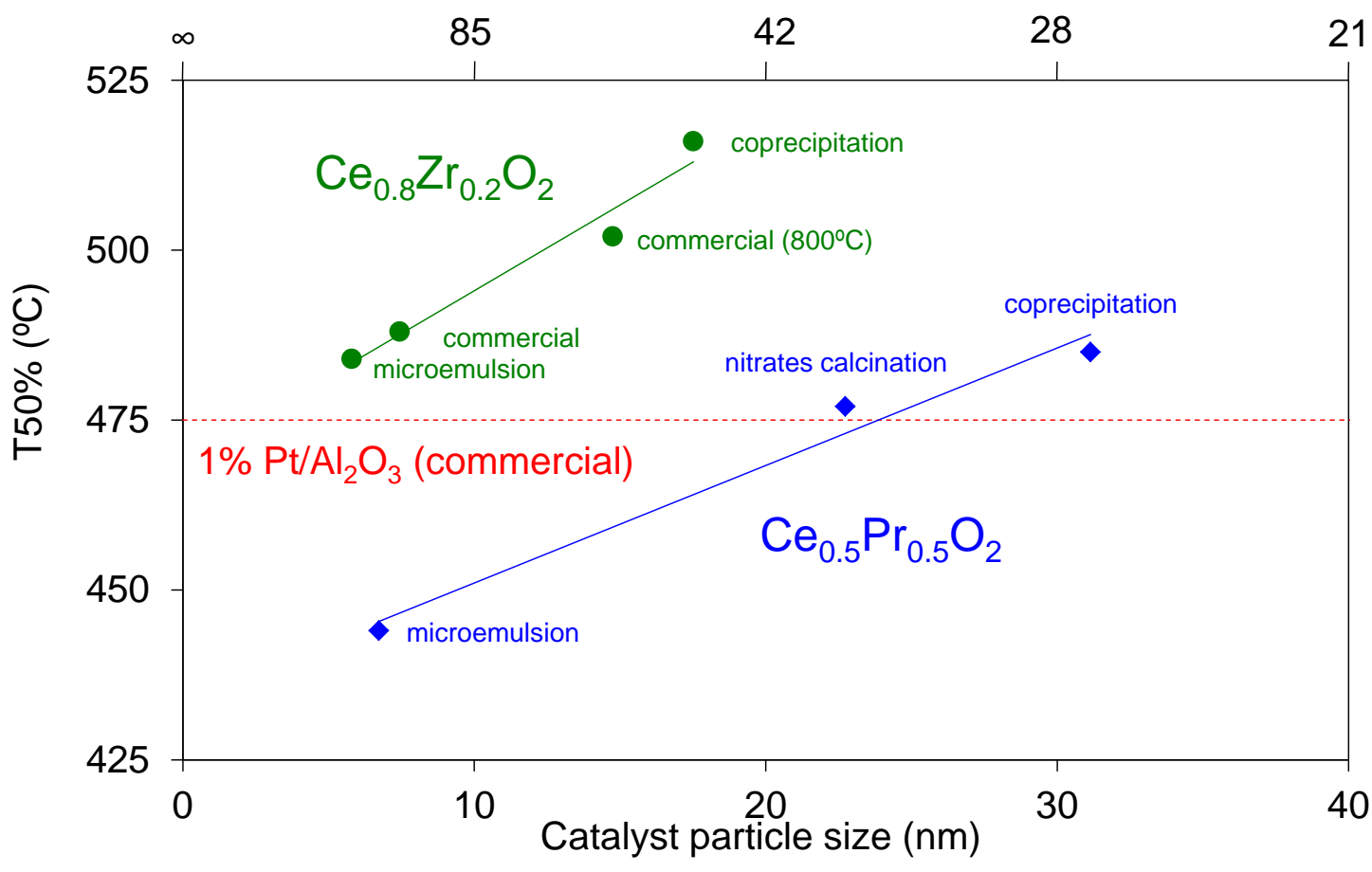

